\title{
Intergenerational Transgressions in Re-living War and the Uncertainty of Displacement: A Privilege or a Curse for the Third Generation
}

\begin{abstract}
Transgression is often seen as a negative term; to cross social or ethical boundaries. In this paper, it is defined as 'blurring of the symbolic boundaries between grandparents and younger generations in terms of the WWII experience', which leads to living memory of the war, but also to experiencing and re-living the trauma of war and dislocation. It occurs through the immersion of younger generations in family history narratives, memorabilia, diaries and photographs that become a family treasure, owned jointly by the family members. In this paper, intergenerational transgression is analysed as a soft and symbolic phenomenon, which on one hand preserves the memory of past, but on the other, cascades the negative experiences onto children and grandchildren. If this is true for WWII survivors, then it should be considered in other cases of long-term conflict and dislocation, particularly in recent conflicts such as Syria, Iraq, and Afghanistan.
\end{abstract}

Understanding the connection between intergenerational transgression of war trauma may aid the process of healing.

\section{Keywords:}

trauma transmission, historical trauma, WWII, generations, healing, social pedagogy

1 The Maria Grzegorzewska University in Warsaw, Warsaw, Poland. E-MAIL: acoates@aps.edu.pl ORCID: 0000-0002-2112-8711 


\section{INTRODUCTION}

The paper is based on a purposively selected literary review of existing scientific works dedicated to the transmission of war related trauma and its impact on younger generations, due to familial transfer of trauma. Albeck (1994) describes the experience of intergenerational transmission of trauma as having scars on one's body without suffering the actual wounds that would have caused them. Transmission of trauma is demonstrated by secondary traumatization, suffered by children of original victims (Giladi \& Bell, 2013), impacting on their future functioning, their parenting and interpersonal relationships.

To show the depth and lasting power of intergenerational transgression, the focus is placed primarily on the first and the third generation. The paper is inspired by a personal experience of intergenerational transgression. Therefore, the notion of this phenomenon derives from the author's autobiographical exploration included in this paper. The paper may be inscribed into the field of social pedagogy, social psychology and political sociology, related to the subjects of memory, social conditioning and the intergenerational transmission of war related trauma. Moreover, Jan Assmann's (2006, 2008) understanding of historic memory (individual, social, communicative or cultural) will be enhanced by the accompanying, deep, inherent experience of trauma embedded in historic events. It is the very experience of trauma that should be identified, addressed, understood and resolved in a multigenerational perspective.

Therefore the overall aim of this paper is to hypothesize a novel approach to the phenomenon of 'intergenerational transgression', starting with an alternative definition and closing with a predisposition to identify the socio-pedagogical healing potential of such explorations. This is not to say that the individual cases of WWII generation and their children, or the trauma suffered by the indigenous population of North America, may be easily adopted in the 21st century liquid social reality, yet the educators and social workers connecting with today's victims of Syria, Iraq and Afghanistan's military conflicts and forced displacements, may be better equipped to support generations to come, in building resilience and a brighter future. Within understanding starts the process of healing (cf. Sieff, 2015).

\section{INTERGENERATIONAL TRANSGRESSION}

'Transgression' is often seen as a negative term connected with the crossing of social norms and ethical boundaries (cf. Asquith \& Cheers, 2001; Austin et al., 2006). 
It is also associated with group violence (Goode \& Smith 2016). In the intergenerational context, it may be viewed as the sins of grandparents, where the current generation is held to account for the transgressions of previous generations (Goto et al., 2015; Bulus Takore, 2017). Transgression is also recognized as a process of deep engagement and self-association with the story or narrative by their readers (cf. Newman, 1993). In this paper, the meaning of 'intergenerational transgression' is understood in an alternative way, directed at the 'blurring of the symbolic boundaries' between grandparents (great-grandparents or parents) and younger generations in terms of the WWII experience, which may lead to the living memory of war, which may also transmit intergenerational emotional damage and anxiety. Intergenerational transgression, in this understanding, is therefore a soft and symbolic phenomenon difficult to capture in socio-pedagogical research. This phenomenon may occur through the immersion of younger generations in family history narratives that become a family treasure, owned jointly by the family members (although it may also be represented by inheritable post-traumatic stress). Possessions such as memorabilia play an important part in this process: family treasures connected to war, documents, photographs, war and after-war diaries. The transgression may be also observed in an increased interest and knowledge of WWII, derived from books and documentaries, in thinking about it often, in commemorating it, remembering it and may also refer to a 'set of values' transmitted to younger generations. Intergenerational transgression is connected to, but not to be confused with, intergenerational transmission (Hareven, 1994), which is a transmission of family norms and values and family history from an older generation to younger generations, for the continuation and reproduction of both wider culture and the unique familial individuality (cf. Rosenthal \& Marshall, 1988; Sabatier \& Lannegrand-Willems, 2005). Transmission may also be associated with transferring trauma and suffering from a post-traumatic stress onto one's own children or/and grandchildren.

Nevertheless, intergenerational transgression is more than just a transmission, it leads to immersion in past experience and the blurring of age-gap boundaries, time and emotional ballast. Amongst the distinctive features of such transgressions are a differing perception of family and intergenerational commitments and a certain feeling of indebtedness (cf. Wątroba, 2017). Wesołowski (1995, p. 12) talks about transgression in terms of transactional interests, seeing it as a method to overcome the past and build the future, based on collective tradition and shared memory. The notion of intergenerational indebtedness may also be found in Bengston et al. (1985) and McPherson (1998) who discuss successful transfer of values held responsible for intergenerational relationships in the process of aging and care. These ideas about alternative meanings of transgression require that it must con- 
stitute a fully conscious and controlled process. On the contrary, this paper claims that it is a spontaneous and independent social phenomenon, which may become more controlled and people may become more conscious of it in the future, when experienced by the new generations involved in the 21st century's conflicts. This will depend on education and support received by victims and their families. An expert on the memory of the WWII, Wiesław Theiss $(2017)^{2}$, coined the phrase: 'grandchildren with an excess of memory baggage', alongside their parents ('the generation after') and their grandparents ('the generation of the apocalypse'). This term implies a certain negative ballast carried on the shoulders of the third generation and this is the first path chosen to analyse in this paper - the unintentional passing on of trauma from grandparents to their grandchildren.

\section{INTERGENERATIONAL TRANSMISSION OF TRAUMA AS EVIDENCE FOR INTERGENERATIONAL TRANSGRESSION}

Intergenerational transmission of trauma has been of interest to clinical psychologists for a long time, including Levi, Wiesel, Kernberg, Ferenczi, Freud and Laub. Auerhahn \& Laub (1998, p. 22) wrote poignantly:

knowledge of psychic trauma weaves through the memories of several generations, making those who know it as secret bearers. [...] massive trauma has an amorphous presence, not defined by place or time and lacking a beginning, middle, or end [...], it shapes the internal representation of reality of several generations, becoming an unconscious organizing principle, passed on by parents and internalized by their children.

Becker and Diaz (1998) found that children and grandchildren, of those who suffered from the dictatorship in Latin America, shared the deep trauma of their parents and grandparents, identifying with it as if it was their own first-hand experience. Werner Bohleber (2007) identified the need to recognize and to analyze historical facts in trauma patients lives, together with their long-term intergenerational outcomes. Myhra (2011) also confirmed that trauma may be inherited, as she linked intergenerational transmission of historical trauma with substance abuse among America's and Alaska's indigenous people. In fact, in a native American cultural context, the intergenerational transfer of behavioral models of either malfunction-

2 Presentation at Janusz Korczak’s Congress of Children Rights, which took place in Warsaw, Poland, POLIN 23-24 September 2017. 
ing or adaptation and resilience, is claimed to be based on passing on the historical trauma from one generation to another as described by Brave Heart (2003) and by Morgan \& Freeman (2009). More recently, a multi-perspective book by Clara Mucci (2013) focuses on intergenerational transmissions, utilizing this term as a way to overcome the limiting division into personal vs. collective trauma. In the sociopolitical context of this paper, one must mention Kraaykamp \& Nieuwbeerta's (2000) study of the 'intergenerational transmission' in 5 former socialist societies (including Poland). However terminologically relevant, this geographically pertinent study does not cover the socio-cultural aspects related to shared memory of WWII, but the intergenerational transmission of 'wealth'. So the main common point of reference is the use of relevant terminology. Equally, 'intergenerational transmission', that is, the core subject of this discussion, should be viewed as a socially mediated process of preserving memory and culture through and within family narratives and as such should not be muted but worked with (cf. Coker, 2008; Schönpflug, 2001). Furthermore, the memory of war is likely to be tainted by a 'secondary trauma experience', passed on from parents to children, as proven by Motta et al. (1997), who positively tested a modified 'Stroop procedure' (test measuring trauma by response to context driven words, displayed in different colours), to assess stress in post-Vietnam veterans and non-veteran children. Moreover, Nicolai, Zerach, \& Solomon (2017) researched intergenerational transmission of captivity trauma amongst children of fathers suffering from a post-traumatic stress disorder and found statistically valid correlation. Intergenerational transmission of trauma often refers to parents passing on their trauma onto their children and in reference to WWII these are/were often Holocaust survivors (Katz, 2003; Prager, 2003).

Wider meta-analysis of studies dedicated to intergenerational transmission of parental trauma onto younger generations were carried out by clinical psychologist Irit Felsen (2017), being probably the most comprehensive to date. Felsen not only provides research relevant to the issues of intergenerational transmission of trauma, but most importantly builds a hub of evidence that appropriate interventions aimed at supporting survivors of trauma, together with family support, may normalize and improve relational functioning on personal, spousal, and parental level. This is extremely important for sheltering children and grandchildren from the intergenerational transmission of negative consequences, associated with posttraumatic responses in care providers, either parents or grandparents. Amongst the case studies presented in Felsen's work, one may find the already mentioned intergenerational transmission of a "historical trauma", recognized by Sotero (2006), Kupelian, Sanentz, \& Kassabian (1998), Harth (2001), or Field, Muong, \& Sochanvimean (2013). Further confirmation that differences and vulnerabilities 
were also found in children of trauma survivors who did not even experience first-hand trauma was delivered by Yehuda et al. (2014). Furthermore, the Second World War's survivors who were separated from their families due to evacuation as children, suffered from many emotional and relational issues, passed down in some forms to their own children and grandchildren (cf. Pesonen et al., 2007; Andersson, 2011, Foster, Davies, \& Steele, 2003; Waugh et al., 2007; Teegen \& Meister, 2000; Kuwert et al., 2007). Trauma of the Holocaust has been carried forward from generation to generation, according to Danieli (1984), Stern (2000), Davidovitch \& Zalashik (2007), Friedman-Peleg (2014), and Lenoff (2014). Amongst the long-term effects suffered by 3 generations of Holocaust survivors, Scharf \& Mayseless (2011) recognized a lack of emotional resources, inability to express autonomous wishes, disorganizing and coercive experiences within familial relationships. Other researchers found an overprotective parental style and the limiting of the agency of children amongst parents and grandparents who experienced the trauma of war (Bar-On et al., 1998; Brom, Kfir, \& Dasberg, 2001; Kellermann, 2001). Felsen (1998) established that experiences of anxiety, depression, guilt and self-criticism were highly overrepresented amongst the children and grandchildren of the war survivors, who were also less willing to separate from their parents (Brom, Kfir, \& Dasberg, 2001) and had poorer parental self-representation (Scharf, 2007). Hesse \& Main (2006) linked these to the unresolved early trauma in parents' and grandparents' lives, which is responsible for a disoriented attachment style displayed by their children ${ }^{3}$.

The transmission of war trauma between generations may be a representation of war related intergenerational transgression. D. Laub (2009) writes about the necessity to find an external point of reference to link the current emotional issues with historical events, which in cases of second and third generation survivors of the holocaust dates back to WWII. The difficulty in the identification and therapeutic response to trauma transmitted onto younger generations comes from the ambiguous and vague indication of the original historic cause by members of family, who may often be unaware that they suffer from inherited post traumatic stress and pass it on to their children and grandchildren in a repeated pattern (cf. Bradfield, 2011). To understand the interrelationship with traumatic events of the past and how it shapes relationships and functioning in the present is important if we aim to encourage the process of healing amongst past, present and future generations (Brave Heart \& DeBruyn, 1998, p. 76).

3 The notion of reactive attachment disorder (RAD) may be found in a volume of studies and personal accounts, dedicated to Holocaust survivors and their children, eg., Braga, Mello, \& Fiks (2012); Fonagy (1999); Hoffman (2004); Rapoport (2011); Rowland-Klein \& Dunlop (1998). 


\section{TOWARDS RESILIENCE AND RECOGNITION - AN AUTOBIOGRAPHICAL CASE STUDY}

In some studies carried out in times of peace, one may find that intergenerational narratives help young people in their self-assessment and are relevant to the general feeling of wellness amongst them (Fivush, Bohanek, \& Duke, 2008; Fivush et al., 2011; Fivush \& Zaman, 2011; Merrill \& Fivush, 2016). Intergenerational narratives that deal with transgressive issues (understood as crossing of the moral boundaries) were found to be particularly relevant (Mansfield, McLean, \& Lilgendahl, 2010). War is one of the most challenging times and times of countless moral transgressions. A personal, autobiographical case study aims to add to this discussion in the context of 'intergenerational transgression' and to its positive meaning. The cause of such transgression is yet to be established, but the intergenerational transmission of memory in individual biographical narrative will be clearly visible (cf. Svob et al., 2016). Perhaps it was the strength of the interpersonal bond, due to the amount of time invested in togetherness that led to the experience of intergenerational transgression of WWII. Perhaps it was the charismatic personality and the strength of character of the WWII survivor. Maybe it was the importance of the results of WWII for the future of the country and its citizens, or maybe all of these factors together. Either way, the phenomenon of intergenerational transgression is something that the Author of this paper experienced personally, through direct and intense contact with her grandfather, who told her war stories every single day. They played war games and read books dedicated to WWII. Although she did not experience the war herself, she often felt like she did. It was as if it was part of her and she had seen it and participated in it through the eyes and experiences of her grandfather. It was real and alive for her. She also noticed that other people of her age or even younger, in her social environment, shared a similar experience. She says: "Although I did not experience the Second World War in person, I lived it every day for the first 23 years of my life".

Grandfather ${ }^{4}$ was a retired colonel, rejected from the Polish military after his return to Poland from England in 1946. His alliance as an operational officer with Anders' Army was considered treason by the communist government and he was expelled from military service. In order to survive, he had to complete an additional MSc in economics to be able to perform any paid employment at all. At his final working years, he worked as an account in the shipyards in Gdańsk and was subjected to regular supervision of special forces and reports were written

4 https://pl.wikipedia.org/wiki/Zygmunt_Odrow\%C4\%85\%C5\%BC-Zawadzki. 
about his activities, his guests and his whereabouts. At this late period in his life, regular calls to visit a police station seized. Despite government supervision, he regularly visited the graves of heroes and former soldiers of WWII, both in Poland and abroad, taking his granddaughter to several ceremonies a year, amongst them commemoration ceremonies at Westerplatte, Bzura battle reconstructions near Sochaczew, multiple celebrations at the British Embassy in Warsaw, visits to Monte Cassino, Bologna and Ancona. These may be viewed as an opportunity for a child participation in important historic and political events. He gave passionate speeches at ceremonies, at schools and in churches. He wore his uniform for special occasions and a collection of medals awarded to him for bravery and war time achievements, including an MBE and the Virtuti Militari that he treasured the most. He linked many factors of life and current affairs to the war time experiences. At the age of 70, he resigned from work to look after his granddaughter when she turned 2 years old. He made war references to all the fun activities including playing shops and dolls, he sung war songs, told war rhymes, read stories from the battlefields, bought model soldiers, plastic guns, little tanks, military boats, aircraft, and had her build cardboard models. Playing chess was always performed like a real political battle between two real political entities. He bought his granddaughter the Trilogy ${ }^{5}$ by H. Sienkiewicz when she was 4 and she had read it 3 times by the age of 7. Playing cards and chess, taking on the roles of the soldiers of two opposing armies, climbing trees, hiding in holes and behind hills, had a flavour of military training and for a small girl it felt truly exciting. Philosophical debates took place over the chess board about right and wrong decisions and how they affect simple regular soldiers and their families. No man was to be sacrificed in the battle unnecessarily. The ultimate goal was to protect the royal couple, but the cost was always analysed. The implications were often considered against patricians, uprisings and political changes in the positioning of Polish boarders. Moreover, prayers were said before the battles began. The battle fields were drawn, trenches were built in the woods and pretend fights with home-made swords and bows and arrows were a common pass-time activity. As the old soldier was preparing his memoirs, first drafts of manuscripts containing encyclopaedic references to war and newly drafted chapters for war related books were read and reread at midday breaks or as night-time story reading. From a perspective of time, this may sound not quite like games and fun for a small child, yet it felt fantastic and adult-like. Grandmother's stories of carrying underground press through the mountains,

5 A patriotic novel about 17th century conflicts of Polish empire with Cossacks, Swedish and Ottoman empire. 
where she was hiding during the Nazi occupation, or the story of being almost shot dead and being rescued from a work camp in Mecklenburg (Germany) were also present at domestic dinner discourses, but less in-depth and less in-detail.

The tension and antagonism between the communist state with their secret service, phone bugging and the snooping of neighbours added to the ongoing war-like atmosphere, which slowly defused after 1990. Suddenly communism ended and it became easier to talk about WWII in public and to celebrate forgotten heroes. New publication opportunities emerged and grandfather became engaged in the writing of his personal memoirs and a monograph of Poznań's 14th Infantry Division. This resulted in a pile of books and articles bought in for reference to again raise the topic of war and to take over the thoughts and conversations in the household. Regular parties were held with former soldiers and officers discussing and mitigating historical truths and errors. In such a social ambient it was impossible to escape a daily portion of WWII in everyday life. Free press and the newly established open media became interested in surviving commanding officers from Anders' Army, who were still alive and willing to give interviews and public appearances. All of this led to the final recognition of grandpa's war achievements by President Lech Kaczyński, who promoted him to a retired brigadier general in $2006^{6}$ and the anguish he felt for not being able to continue his military service was finally resolved.

Throughout the Author's childhood years, the whole family life circled around this very issue, how the communist leaders treated WWII heroes and how to avoid indoctrination and bending of the truth. Individual memory of the first-hand truth about the war, from the eye witness accounts, was considered of primary importance for collective memory building. Family 'accomplishment' relied in great part on a successful transmission of WWII memory to the younger generation. This may be a shared experience of many other grandchildren, raised in times of communism. Some of these grandchildren have been identified as they are members of historic reconstruction groups and research into their experiences, which is taking place in 2018-2019 as part of a project funded by The Maria Grzegorzewska University in Warsaw, dedicated to: "WWII - Intergenerational transgressions. Socio-historical implications”, carried out in cooperation with Jacek Kulbaka and Bartosz Gondek. For the members of the reconstruction groups, collecting war memorabilia, dressing up in historic uniforms and re-enacting historic facts, battles or tragedies, is an expression of public history, or 'lived' history. It is not only

6 http://ww w.prezydent.pl/archiwum-lecha-kaczynskiego/aktualnosci/rok-2008/ art,148,1021,pozegnanie-generala-zygmunta-odrowaza-zawadzkiego.html. 
a way of preserving history but also of 're-living' it (as expected per intergenerational transgression) and passing it on to new generations.

According to Tappan (1991; 1998, p. 151), narratives mould children's moral attitudes, working as models for extrapolating moral dilemmas to shape and to reconcile, through hoisting moral emotions (cf. Fivush et al., 2014). Discussing death and trauma, considering political decisions and battlefield leadership, balancing responsibility and necessities of the time, in spite of the audience, creates an open space for childhood reflexivity, participation and feelings of indebtedness, associated with responsibility, which preconditions childhood resilience and self-determination. This may be considered to be the path of hope, where first generation unwillingly passes on their unresolved trauma to their children, who then unknowingly pass it on to their own children. However, at this point, the first generation may grow to reconstruct and rework their initial trauma to strengthen and support their grandchildren. Similar findings of increased resilience in WWII survivors in their grandparental roles and a positive impact on their grandchildren were reported by Sagi-Schwartz et al. (2008).

\section{'PARRHESIA' IN THE PROCESS OF HEALING}

In this case, the WWII participant's attitude to passing on the living memory of the war falls into M. Foucault's understanding of 'parrhesia' (1983) as speaking freely about truth, with frankness considered as duty. Similarly, to Foucault's conceptualization, it carries a burden of danger and takes courage to tell the truth when surrounded by an oppressive regime (cf. Foucault, 1983, pp. 15-16). Moreover, 'parrhesia' is expressed through speaking feely about the truth with frankness and despite the danger to one's own life. It includes self-criticism and criticism of others, embracing moral duty through freedom of choice (cf. Foucault, 1983, pp. 19-20), the right and the obligation for future generations. This is a complex and quite sophisticated matter. On one hand, there is the individual experience that adds to the preservation of social and collective memory, on the other, the associated trauma and its ongoing transmission to younger generations. There is a delicate balance to be found between the responsibility to preserve memory of the past and the responsibility of not passing unresolved trauma onto younger family members. This balance relies on self-awareness and the awareness of intergenerational transgression. In the context of memory and especially memory tainted with tragedy and trauma, Rodriguez \& Fortier (2007, pp. 55-84) believe in the power of narrative, being the cornerstone of the process of resistance-building and 
a healthy individual and collective identity. Such interpretation of a narrative may bring intergenerational transfer of trauma into the open and enable the identification of personal and relational issues, in order to find appropriate help and support for an entire family, regardless of generational order.

\section{CONCLUSION}

Social pedagogues are neither psychologists nor therapists, yet they often discover children and families who have experienced the intergenerational transmission of trauma, often related to war, forced separation and forced dislocation. An understanding of intergenerational trauma transfers and intergenerational transgressions of war is important in social work for the identification of support needs and the activation of the correct environmental resources. It also enriches the academic discourse of social pedagogy, dedicated to social phenomenon related to memory and intergenerational transmission of cultural and historic heritage. The lack of such knowledge may endanger relational mediation and emotional healing. "Healing is an experiential, energy-requiring process in which space is created through a caring relationship in a process of expanding consciousness and results in a sense of wholeness, integration, balance and transformation and which can never be fully known” (Wendler, 1996, p. 836). Therefore, academic contributions that aid the healing process should not be disregarded and the concept of intergenerational transgressions should be investigated further and considered more universally.

There is yet another dimension to reflect on whilst supporting the family in this complex intergenerational transgression. The burden that may be passed on from the supported family to the professional, who becomes the 'engaged witness' in order to help the family to integrate and to overcome unbearable, intergenerational experiences (cf. Gerson, 2009). Such discussion, however, will not take place in this paper as it is outside its scope of shedding a fresh light on the phenomenon of intergenerational transgression.

\section{References}

Albeck, J.H. (1994). Intergenerational Consequences of Trauma: Reframing Traps in Treatment Theory - A Second Generation Perspective. In: E.B. Williams \& J.F. Sommer (Eds.), Handbook of Post-traumatic Therapy (pp. 106-125). Westport, CT: Greenwood Press.

Andersson, P. (2011). Post-traumatic Stress Symptoms Linked to Hidden Holocaust Trauma among Adult Finnish Evacuees Separated from Their Parents as Children in World War II, 1939-1945: A Case-control Study. International Psychogeriatrics, 23(4), pp. 654-661, DOI: 10.1017/S1041610210001791. 
Asquith, M., \& Cheers, B. (2001). Morals, Ethics and Practice - in Search of Social Justice. Australian Social Work, 54(2), pp. 15-26. DOI: 10.1080/03124070108414320.

Assmann, A. (2006). Memory, Individual and Collective. In: E. Goodin \& C. Tilly (Eds.), The Oxford Handbook of Contextual Political Analysis (pp. 210-224). Oxford: Oxford University Press.

Assmann, J. (2008). Communicative and Cultural Memory. In: A. Erll \& A. Nünning (Eds.), Cultural Memory Studies: An International and Interdisciplinary Handbook (pp. 109-118). Berlin, New York: Walter de Gruyter.

Auerhahn, N., \& Laub, D. (1998). Intergenerational Memory of the Holocaust. In: Y. Danieli (Ed.), International Handbook of Multigenerational Legacies of Trauma (pp. 21-42). New York: Plenum Press.

Austin, W., Bergum, V., Nuttgens, S., \& Peternelj-Taylor, C. (2006). A Re-Visioning of Boundaries in Professional Helping Relationships: Exploring Other Metaphors. Ethics \& Behavior, 16(2), pp. 77-94. DOI: 10.1207/s15327019eb1602_1.

Bar-On, D., Eland, J., Kleber, R.J., Krell, R., Moore, Y., Sagi, A., Soriano, E., Suedfeld, P., van der Velden, P.G., \& van IJzendoorn, M.H. (1998). Multigenerational Perspectives on Coping with the Holocaust Experience: An Attachment Perspective for Understanding the Developmental Sequelae of Trauma across Generations. International Journal of Behavioral Development, 22(2), pp. 315-338, DOI: 10.1080/016502598384397.

Becker, D., \& Diaz, M. (1998). The Social Process and the Transgenerational Transmission of Trauma in Chile. In: Y. Danieli (Ed.), International Handbook of Multigenerational Legacies of Trauma (pp. 435-446). New York: Plenum Press.

Bengston, V.L., Cutler, N.E., Mangen, D.J., \& Marshall, V.W. (1985). Generations, Cohorts, and Relations between Age Groups. In: R. H. Binstock \& E. Shanas (Eds.), Handbook of Aging and the Social Sciences (pp. 304-338). York: Van Nostrand Reinhold.

Bohleber, W. (2007). Remembrance, Trauma and Collective Memory: The Battle for Memory in Psychoanalysis. The International Journal of Psychoanalysis, 88, pp. 329-352.

Braga, L.L., Mello, M.F., \& Fiks, J.P. (2012). Transgenerational Transmission of Trauma and Resilience: A Qualitative Study with Brazilian Offspring of Holocaust Survivors. BMC Psychiatry, 12, pp. 134-145.

Brave Heart, M.Y.H. (2003). The Historical Trauma Response among Natives and Its Relationship with Substance Abuse: A Lakota Illustration. Journal of Psychoactive Drugs, 35(1), pp. 7-13. DOI: 10.1080/02791072.2003.10399988.

Brave Heart, M.Y.H., \& DeBruyn, L.M. (1998). The American Indian Holocaust: Healing Historical Unresolved Grief. American Indian and Alaska Native Mental Health Research, 8(2), pp. 56-78. DOI: 10.5820/aian.0802.1998.60.

Brom, D., Kfir, R., \& Dasberg, H. (2001). A Controlled Double-blind Study on Children of Holocaust Survivors. The Israel Journal of Psychiatry and Related Sciences, 38(1), pp. 47-57.

Bradfield, B. (2011). The Dissociation of Lived Experience: A Relational Psychoanalytic Analysis of the Intergenerational Transmission of Trauma. International Journal of Psychoanalytic Self Psychology, 6(4), pp. 531-550. DOI: 10.1080/15551024.2011.606953.

Bulus Takore, Z. (2017). Sin of the Fathers upon the Children to the Third and Fourth Generation: An Appraisal of Exodus 20:5 and Deuteronomy 5:9 in Relation to an African Theo- 
logical Understanding of Original Sin. PhD Thesis. Retrieved from: http://hdl.handle. net/10019.1/101128.

Coker, C. (2008). War, Memes, and Memeplexes. International Affairs, 84(5), pp. 903-914. DOI: 10.1111/j.1468-2346.2008.00745.x.

Danieli, Y. (1984). Psychotherapists' Participation in the Conspiracy of Silence about the Holocaust. Psychoanalytic Psychology, 1(1), pp. 23-42.

Davidovitch, N., \& Zalashik, R. (2007). Recalling the Survivors: Between Memory and Forgetfulness of Hospitalized Holocaust Survivors in Israel. Israel Studies, 12(2), pp. 145-163. DOI: 10.2307/30245665.

Felsen, I. (1998). Transgenerational Transmission of Effects of the Holocaust: The North American Research Perspective. In: Y. Danieli (Ed.), International Handbook of Multigenerational Legacies of Trauma (pp. 43-67). New York: Plenum Press.

Felsen, I. (2017). Adult-onset Trauma and Intergenerational Transmission: Integrating Empirical Data and Psychoanalytic Theory. Psychoanalysis, Self and Context, 12(1), pp. 60-77. DOI: 10.1080/15551024.2017.1251185.

Field, N.P., Muong, S., \& Sochanvimean, V. (2013). Parental Styles in the Intergenerational Transmission of Trauma Stemming from the Khmer Rouge Regime in Cambodia. American Journal of Orthopsychiatry, 83(4), pp. 483-494. DOI: 10.1111/ajop.12057.

Fivush, R., Bohanek, J.G., \& Duke, M. (2008). The Intergenerational Self: Subjective Perspective and Family History. In: F. Sani (Ed.), Self-Continuity: Individual and Collective Perspectives (pp. 131-144). Mahwah, NJ: Erlbaum.

Fivush, R., Habermas, T., Waters, T.E.A., \& Zaman, W. (2011). The Making of Autobiographical Memory: Intersections of Culture, Narratives, and Identity. International Journal of Psychology, 46(5), pp. 321-345. DOI: 10.1080/00207594.2011.596541.

Fivush, R., Merrill, N., \& Marin, K. (2014). Voice and Power: Constructing Moral Agency through Personal and Intergenerational Narratives. In: C. Wainryb, \& H.E. Recchia (Eds.), Talking about Right and Wrong: Parent-Child Conversations as Contexts for Moral Development (pp. 270-296). Cambridge: Cambridge University Press.

Fivush, R., \& Zaman, W. (2011). Intergenerational Narratives: How Collective Family Stories Relate to Adolescents' Emotional Well-being. Aurora, 10, pp. 51-63.

Fonagy, P. (1999). Attachment, the Holocaust and the Outcome of Child Psychoanalysis: An Attachment-based Model of Transgenerational Transmission of Trauma. Paper presented at the Sophia Mirviss Memorial Lecture, San Francisco Psychoanalytic Institute and Society: San Francisco.

Foster, D., Davies, S., \& Steele, H. (2003). The Evacuation of British Children during World War II: A Preliminary Investigation into the Long-term Psychological Effects. Aging \& Mental Health, 7(5), pp. 398-408. DOI: 10.1080/1360786031000150711.

Foucault, M. (1983). Discourse and Truth: The Problematization of Parrhesia (Six Lectures). The University of California: Berkeley.

Friedman-Peleg, K. (2014). The Nation on the Couch (Hebrew). Jerusalem: Magnes Publishers.

Gerson, S. (2009). When the Third is Dead: Memory, Mourning and Witnessing in the Aftermath of the Holocaust. International Journal of Psychoanalysis, 90(6), pp. 1341-1357. DOI: 10.1111/j.1745-8315.2009.00214.x. 
Giladi, L., \& Bell, T.S. (2013). Protective Factors for Intergenerational Transmission of Trauma among Second and Third Generation Holocaust Survivors. Psychological Trauma: Theory, Research, Practice, and Policy, 5(4), pp. 384-391. DOI: 10.1037/a0028455.

Goode, C., \& Smith, H.J. (2016). Retribution or Restoration: Symbolic Justice Concerns Shape How Victim Group Members React to Intergroup Transgressions. Current Opinion in Psychology, 11, pp. 105-109. DOI: 10.1016/j.copsyc.2016.07.003.

Goto, N., Jetten, J., Karasawa, M., \& Hornsey, M.J. (2015). The Sins of Their Fathers: When Current Generations Are Held to Account for the Transgressions of Previous Generations. Political Psychology, 36(4), pp. 479-487. DOI: 10.1111/pops.12172.

Hareven, T.K. (1994). Aging and Generational Relations: A Historical and Life Course Perspective. Annual Review of Sociology, 20, pp. 437-461. DOI: 10.1146/annurev. so.20.080194.002253.

Harth, E. (2001). Last Witnesses: Reflections on the Wartime Internment of Japanese Americans. New York: Palgrave.

Hesse, E. \& Main, M. (2006). Frightened, Threatening, and Dissociative Parental Behavior in Low-Risk Samples: Description, Discussion, and Interpretations. Development and Psychopathology, 18(2), pp. 309-343.

Hoffman, E. (2004). After Such Knowledge. NY: Public Affairs.

Katz, M. (2003). Prisoners of Azkaban: Understanding Intergenerational Transmission of Trauma Due to War and State Terror (With Help from Harry Potter). Journal for the Psychoanalysis of Culture \& Society, 8(2), pp. 200-207. DOI: 10.1353/psy.2003.0037.

Kellermann, N.P. (2001). Perceived parental rearing behavior in children of Holocaust survivors. Israel Journal of Psychiatry and Related Sciences, 38(1), pp. 58-68.

Kraaykamp, G., \& Nieuwbeerta, P. (2000). Parental Background and Lifestyle Differentiation in Eastern Europe: Social, Political, and Cultural Intergenerational Transmission in Five Former Socialist Societies. Social Science Research, 29(1), pp. 92-122. DOI: 10.1006/ ssre.1999.0655.

Kupelian, D., Sanentz, A., \& Kassabian, A. (1998). The Turkish Genocide of the Armenians: Continuing Effects on Survivors and Their Families Eight Decades after Massive Trauma. In: Y. Danieli (Ed.), International Handbook of Multigenerational Legacies of Trauma (pp. 191-210). New York: Plenum Press. DOI: 10.1007/978-1-4757-5567-1_13.

Kuwert, P., Spitzer, C., Trader, A., Freyberger, H.J., \& Ermann, M. (2007). Sixty Years Later: Post-traumatic Stress Symptoms and Current Psychopathology in Former German Children of World War II. International Psychogeriatrics, 19(5), pp. 955-961. DOI: 10.1017/ S104161020600442X.

Laub, D. (2009). On Holocaust Testimony and Its "Reception” within Its Own Frame, as a Process in Its Own Right: A Response to "Between History and Psychoanalysis" by Thomas Trezise. History and Memory, 21(1), pp. 127-150. DOI: 10.1353/ham.0.0018.

Lenoff, L. (2014). Cumulative Trauma and Relational Competence. Psychoanalytic Inquiry, 34(1), pp. 63-74. DOI: 10.1080/07351690.2014.859895.

Mansfield, C.D., McLean, K.C., \& Lilgendahl, J.P. (2010). Narrating Traumas and Transgressions: Links between Narrative Processing, Wisdom, and Well-being. Narrative Inquiry, 20(2), pp. 246-273. DOI:10.1075/ni.20.2.02man.

McPherson, B.D. (1998). Aging as a Social Process. 3rd Ed. Toronto: Harcourt Brace Canada. 
Merrill, N., \& Fivush, R. (2016). Intergenerational Narratives and Identity across Development. Developmental Review, 40, pp. 72-92. DOI: 10.1016/j.dr.2016.03.001.

Morgan, R., \& Freeman, L. (2009). The Healing of Our People: Substance Abuse and Historical Trauma. Substance Use \& Misuse, 44(1), pp. 84-98. DOI: 10.1080/10826080802525678.

Motta, R.W., Joseph, J.M., Rose, R.D., Suozzi, J.M., \& Leiderman, L.J. (1997). Secondary Trauma: Assessing Inter-generational Transmission of War Experiences with a Modified Stroop Procedure. Journal of Clinical Psychology, 53(8), pp. 895-903.

Mucci, C. (2013). Beyond Individual and Collective Trauma: Intergenerational Transmission, Psychoanalytic Transmission and the Dynamics of Forgiveness. London: Karnac.

Myhra, L.L. (2011). 'It Runs in the Family': Intergenerational Transmission of Historical Trauma among Urban American Indians and Alaska Natives in Culturally Specific Sobriety Maintenance Programs. American Indian and Alaska Native Mental Health Research, 18(2), pp. 17-40.

Newman R.D. (1993). Transgressions of Reading: Narrative Engagement as Exile and Return. Durham and London: Duke University Press.

Nicolai, S., Zerach, G., \& Solomon, Z. (2017). The Roles of Fathers' Posttraumatic Stress Symptoms and Adult Offspring's Differentiation of the Self in the Intergenerational Transmission of Captivity Trauma. Journal of Clinical Psychology, 73(7), pp. 848-863. DOI: $10.1002 /$ jclp.22377.

Pesonen, A., Räikkönen, K., Heinonen, K., Kajantie, E., Forsén, T., \& Eriksson, J.G. (2007). Depressive Symptoms in Adults Separated from Their Parents as Children: A Natural Experiment during World War II. American Journal of Epidemiology, 166(10), pp. 11261133. DOI: $10.1093 /$ aje/kwm254.

Prager, J. (2003). Lost Childhood, Lost Generations: The Intergenerational Transmission of Trauma. Journal of Human Rights, 2(2), pp. 173-181. DOI: 10.1080/147548303200007 8161.

Rapoport, E. (2011). Growing Up in the Shadow of the Holocaust: A Psychoanalyst Addresses Intergenerational Transmission of Trauma in Her Family. Issues in Psychoanalytic Psychology, 33(1), pp. 43-49.

Rodriguez, J., \& Fortier, T. (2007). Cultural Memory: Resistance, Faith, and Identity. Austin: University of Texas Press.

Rosenthal, C.J., \& Marshall, V.W. (1988). Generational Transmission of Family Ritual. American Behavioral Scientist, 31(6), pp. 669-684. DOI: 10.1177/0002764288031006006.

Rowland-Klein, D., \& Dunlop, R. (1998). The Transmission of Trauma across Generations: Identification with Parental Trauma in Children of Holocaust Survivors. Australian and New Zealand Journal of Psychiatry, 32(3), pp. 358-369.

Sabatier, C., \& Lannegrand-Willems, L. (2005). Transmission of Family Values and Attachment: A French Three Generation Study. Applied Psychology, 54(3), pp. 378-395. DOI: 10.1111/j.1464-0597.2005.00216.x.

Sagi-Schwartz, A., Van IJzendoorn, M.H., \& Bakermans-Kranenburg, M.J. (2008). Does Intergenerational Transmission of Trauma Skip a Generation? No Meta-analytic Evidence for Tertiary Traumatization with Third Generation of Holocaust Survivors. Attachment and Human Development, 10(2), pp. 105-121. DOI: 10.1080/14616730802113661. 
Scharf, M. (2007). Long-term Effects of Trauma: Psychosocial Functioning of the Second and Third Generation of Holocaust Survivors. Development and Psychopathology, 19(2), pp. 603-622. DOI: 10.1017/S0954579407070290.

Scharf, M., \& Mayseless, O. (2011). Disorganizing Experiences in Second- and Third-Generation Holocaust Survivors. Qualitative Health Research, 21(11), pp. 1539-1553. DOI: 10.1177/1049732310393747.

Schönpflug, U. (2001). Intergenerational Transmission of Values: The Role of Transmission Belts. Journal of Cross-Cultural Psychology, 32(2), pp. 174-185. DOI: 10.1177/0022022 101032002005.

Sotero, M. (2006). A Conceptual Model of Historical Trauma: Implications for Public Health Practice and Research. Journal of Health Disparities Research and Practice, 1(1), pp. 93-108.

Stern, D.N. (1985). The Interpersonal World of the Infant: A View from Psychoanalysis and Developmental Psychology. London: Karnac Books.

Stern, D.N. (2000). The Present Moment in Psychotherapy and Everyday Life. New York: Norton WW.

Svob, C., Brown, N.R., Takšić, V., Katulić, K., \& Žauhar, V. (2016). Intergenerational Transmission of Historical Memories and Social-distance Attitudes in Post-war Second-Generation Croatians. Memory \& Cognition, 44(6), pp. 846-855. DOI: 10.3758/s13421-0160607-x.

Sieff, D.F. (2015). Understanding and Healing Emotional Trauma: Conversations with pioneering clinicians and researchers. 1st Ed. New York: Routledge.

Tappan, M.B. (1991). Narrative, Authorship, and the Development of Moral Authority. New Directions for Child Development, 54, pp. 5-25. DOI: 10.1002/cd.23219915403.

Tappan, M.B. (1998). Moral Education in the Zone of Proximal Development. Journal of Moral Education, 27(2), pp. 141-160. DOI: 10.1080/0305724980270202.

Teegen, F., \& Meister, V. (2000). Traumatische Erfahrungen deutscher Flüchtlinge am Ende des II. Weltkrieges und Heutige Belastungsstörungen [Traumatic Experiences of German Refugees at the End of World War II and Present Stress Disorders]. Zeitschrift für Gerontopsychologie \& Psychiatrie, 13, pp. 112-124.

Waugh, M.J., Robbins, I., Davies, S., \& Feigenbaum, J. (2007). The Long-term Impact of War Experiences and Evacuation on People Who Were Children during World War Two. Aging \& Mental Health, 11(2), pp. 168-174. DOI: 10.1080/13607860600844473.

Wątroba, W. (2017). Dziedziczenie ubóstwa a dług pokoleniowy [Poverty Inheritance vs. Generational Debt]. Prace Naukowe Uniwersytetu Ekonomicznego we Wrocławiu, 492: Społeczne gospodarowanie, pp. 84-96.

Wendler, M.C. (1996). Understanding Healing: A Conceptual Analysis. Journal of Advanced Nursing, 24(4), pp. 836-842.

Wesołowski, W. (1995). Niszczenie i tworzenie interesów w procesie systemowej transformacji. Próba teoretycznego ujęcia. Kultura i Społeczeństwo, 39(2), pp. 3-26.

Yehuda, R., Daskalakis, N.P., Lehrner, A., Desarnaud, F., Bader, H.N., Makotkine, I., Flory, J.D., Bierer, L.M., \& Meaney, M.J. (2014). Influences of Maternal and Paternal PTSD on Epigenetic Regulation of the Glucocorticoid Receptor Gene in Holocaust Survivor Offspring. American Journal of Psychiatry, 171(8), pp. 872-880. DOI: 10.1176/appi. ajp.2014.13121571. 